\title{
Lecture as an Event in Postdigital Education: a Dyadic Teaching Diary
}

\section{Olli Pyyhtinen ${ }^{1}$ (D) $\cdot$ Juha Suoranta ${ }^{1}$}

Published online: 1 February 2020

(C) The Author(s) 2020

\begin{abstract}
In this experimental text, we reflect in the form of a dyadic teaching diary upon a course we recently taught together on the 'sociological imagination'. One of the main aims we set for the class was to ponder how the social scientific imagination could be enriched, and figure out ways to stress its social and political relevance. From the pedagogical point of view, we wanted to create a course which would disrupt the students' oftcriticized routine of rote-learning, and in which they would learn to use digital platforms for the purpose of producing and sharing knowledge, meet each other, and have their social scientific thinking refreshed and perhaps even renewed. In pondering the weeks spent together with our students, we suggest that what gradually happened in our 'postdigital classroom' and outside of it was an Event-something surprising and unexpected that could not be controlled entirely.
\end{abstract}

Keywords Teaching · Postdigital education · Teaching diary · Flipped classroom • Postdigital event $\cdot$ Sociological imagination

CLOV (wearily):

Same answer.

(Pause.)

You've asked me these questions millions of times.

HAMM:

I love the old questions.

(With fervour.)

Ah the old questions, the old answers, there's nothing like them!

Samuel Beckett, Endgame (1957)

Olli Pyyhtinen

olli.pyyhtinen@tuni.fi

1 Faculty of Social Sciences, Tampere University, Tampere, Finland 


\section{Introduction: Mixing the Dyad}

This is an experimental text, a duoethnography (see Norris et al. 2012), if you like, a teaching diary, and a dyadic study of teaching. It can also be read as a confession in the 'postdigital moment' (Jandrić et al. 2018; Knox 2019) or as a critique of the 'the neoliberal university syndrome' (manifested for instance in the marketization, entrepreneurialization, de-publicization, de-democratization, and in-equalization of the university; see Zuidhof 2015, also Hayes 2019) and as a plea for the 'co-operative and caring university' (see Neary and Winn 2015). For us, the postdigital context, as we have proposed elsewhere, refers, firstly, to 'the multiple use of both digital and traditional information as an ordinary practice'; secondly, to 'the mixing of digital and face-to-face interaction inside and outside the classroom'; thirdly, to 'the fruitful solution of the teacher-student contradiction'; and, fourthly, to 'the expansion of learning via open digital platform such as Wikiversity' (Arndt et al. 2019: 460; see also Jandrić 2017).

The text results from a course that we taught together in Autumn term 2019 at Tampere University in Finland. It is a case of teaching-led research (see e.g. Harland 2016) with a duoethnographic twist, as we did not merely use the course to develop our research in another more or less unrelated context, but the article is precisely about what happened during teaching: we turn our analytical gaze upon ourselves as teachers and reflect on and write about our own personal experiences. Our motives for doing this were not confessional, but we rather wanted, in a synecdochist manner, to extend the personal to the general by connecting it to wider cultural, social, and political constellations, such as the neoliberal university and the postdigital condition. We have chosen this kind of experimental approach for the simple reason that 'much sociological writing', as Berger and Quinney (2005: 10) laconically propose, 'is, quite frankly, dull and turgid'. Disrupting conventional means, forms, and narrative structures of academic writing may spark creativity and imagination. Writing differently may allow scholars to think differently; it may 'unsettle, elude, and perhaps even transform conventional analytic perspectives, explanations, and modes of knowledge production that have become too automatic, stale, and stereotyped', and thus it may 'increase our sensibilities' and open up new ways of perceiving the world (Pyyhtinen 2019: 6-7).

The course we taught centered on the notion of the 'sociological imagination' by $\mathrm{C}$. Wright Mills that he develops in his famous book of the same name published in 1959. We felt that while Mills' book 'is often ritualistically praised' (Swedberg 2014: 195) when the International Sociological Association carried on in the late 1990s, an opinion survey on the most influential sociological books of the twentieth century, The Sociological Imagination came on second place, just after Max Weber's Economy and Society - the role of imagination itself in social science and how it could be cultivated and strengthened has received surprisingly little attention in the reception and uses of the book. And that was our main focus in the course: how the social scientific imagination could be enriched and figure out how it could be made to matter to our students. One of our chief motivations for the course was a concern that theorizing and research are too often understood in an overly narrow and technical manner both in standard courses and textbooks in the social sciences as well as in the scholarly community alike. During the course, we aspired to 'bring the sociological imagination back to life as an adventure of ideas and experimental creation of concepts' (Pyyhtinen 
2015: 2). Thus, we focused on what the social scientific imagination is and what it could be.

From the pedagogical point of view, we wanted to create a course which would disrupt the students' oft-criticized routine of rote-learning, and in which they would learn to use digital platforms for the purpose of producing and sharing knowledge, meet each other, and have their social scientific thinking refreshed and perhaps even renewed. Furthermore, as a teaching dyad, we set out to deconstruct the sovereign and omniscient teacher subject and build a new form of a teacher subject no longer reliant on the single individual. We acknowledged that, as sociologists, we are somewhat different, the one being more a radical public sociologist and the other an unorthodox theorist. But this was not to assert our identities, but we rather wanted to break them open and lay stress on the productivity of differences. Our aim was to no longer be two individual teachers and become a 'production studio' (Deleuze and Parnet 2006: 7) instead. This aim manifests itself also in this text methodologically, as we may sometimes write both in unnamed fluctuating first and second persons and at other times as a communal 'we', acquiring a single voice. It is important to acknowledge that ultimately the text, just like the course itself, is irreducible to either two of us, any more than to the supposedly superindividual imaginary 'we'. The thoughts were not in the one or the other before their manifestation and expression, but stemmed from the give-and-take in-between. So the text rather disrupts or deconstructs a unified author than affirms it. The between, the place from where the text speaks is not itself localizable; it is not here or there but here and there, in the movement from pillar to post.

And yet, the moment we announce that there were two of us, it must be acknowledged that of course we were not alone. It would hardly have made any sense to talk to each other just among the two of us. For this, we would not have needed any course, but we could have done that anywhere we wanted outside the classroom, too, like over a cup of tea or coffee, a lunch, a beer, or by the doorway of the office of either one of us. The teaching dyad is therefore actually a triad or a triangular constellation. It was not solely a relation between $\mathrm{Me}$ and You, self and other, ego and alter, but a Third was involved as well, just as any relation is in fact a configuration of at least three elements. A relation can be adequately thought only by acknowledging the Third, included or excluded, present or absent. The relational withness between-two always assumes or requires a Third, which either precedes the relation, mediates it, or (potentially) disturbs it and is thus excluded. Hence, a relation designates not only directedness toward something other than the self, for the being-toward-another always already implies a Third.

So what/who are the Thirds in this case? Most importantly the participants of the course, the students as our captive audience and interlocutors. Without them there would have been absolutely no point in teaching the course at all. The course actualized as and in a triadic or triangular constellation between You, Me, and the instructed Third' (Serres 1997), that is, the students. But there were other Thirds as well. First of all, technological devices and spaces (e.g. the computers, screens and videprojectors in the lecture hall, and the Internet as the channel of distribution of our reading materials, present such a Third; the notion of the postdigital itself nicely emphasizes how technology is constitutive of the learning environment. Digital technology is an integral part of the postdigital lecture without, however, amounting to a perfectly loyal, 
transparent means. Instead of vanishing into immediacy, it translates and transforms what it mediates and transmits. Yet the Thirds did not stop here. Other Thirds that were present ranged from scholars and their ideas we referred to, the lecture hall itself, as a meeting point between the learned and the novice, and the history of sociology we all carry with us, reproduce, and perhaps sometimes also renew - just to name a few Third partners.

\section{Teaching in a Postdigital Learning Environment}

Usually the students connect to the current neoliberal university by the ear (see Back 2016: 18-19). They are supposed to sit down and listen, as the silent yet (hopefully) attentive Third, though the university management wishes that they do not spend too long a time on their seats listening but move fast on in the school-to-workforce pipeline. Another variation from the theme is that the students sit silently by their computers or handheld devices and obediently do their assignments. This is perhaps what the university management expects from the technological devices: to speed up the studies and thereby save resources. In our course, we wished to undo the conventional, business-as-usual authority structure of the lecture hall by offering the Third an opportunity to speak and have a voice (although we realized that it may also very well refuse to have one) in the classroom and in using digital tools as constitutive parts of our postdigital learning environment. We wanted to flip the classroom by turning the participants from an assumedly passive and silent 'audience' to active co-producers, interlocutors, junior colleagues, and companion teachers, teaching themselves, their fellow students, and us two, too. Whenever the teacher does all the talking, a lecture easily turns into an exercise in intellectual masturbation: a process that may be very pleasurable in itself, but awkward, tiresome, and even appalling for those who have to attest it, and it hardly ever accomplishes anything - pedagogically or otherwise - at the end because of being so self-absorbed. Moreover, we believe that sometimes the conventional classroom situation effectively prevents the students from thinking, as they pass from one lecture to another in a rush. We aspired to turn our course from a listening exercise to an experiment in collective thinking and collaborative learning (see Suoranta 2008), where the outcome can be controlled only partly. From the two of us, this required that we lay down the academic armour and become vulnerable to some extent. It was essential that we put ourselves out there and accept and deal with all the discomfort, fear, risk of failure, and possible shame that comes with it.

We had already taught this course once before in Autumn 2018 (see Arndt et al. 2019: 459-461). So we did not have to create it from scratch. On the contrary, it was already quite well organized and planned in advance. The pedagogical frame was already there. We had our thoughts straight. And yet there was this anxiety and certain nervousness in the air. Are not we all natural-born social constructionists nowadays? And for good reasons. Take the students' point of view. Look at them as they study. We love their group work in our course and we embrace the meaning-work they do in their groups as we do in our discussion lectures and when writing a draft of this text together in the openness of a Wikiversity page. ${ }^{1}$ Wikiversity, one of Wikipedia's sister projects, is an open, multilingual

\footnotetext{
${ }^{1}$ See https://en.wikiversity.org/wiki/Wikiversity:Main_Page. Accessed 20 January 2020.
} 
digital educational resource in the Internet devoted to learning resources, projects, and research for use in all forms and levels of education. What we thus did in practice was 'blended education' in which 'the students access readings, images, and videos on the network while still meeting in class to listen and discuss' (Feenberg 2019: 8). We acknowledge that in such a setting much of what happens in terms of students' learning takes place behind our eyes and ears. And that is perfectly alright. We need not have absolute control. We see that letting go of the idea of perfect control is a necessary part of the notion of the flipped classroom. It is also a way of allowing the students to be active, thinking subjects, capable of organizing themselves. It is about having trust in them. About giving space to lines of flight. The top of the iceberg of learning is visible in the lecture hall, but the rest, the vast magnitude of learning takes place beneath the surface, under the sea, as it were. The tectonic plates move slowly, but occasionally their movement may result in sudden eruptions and earthquakes in the life of mind. Or that is at least what we hope for. As the participants study, they have their devices ready, and through them they literally have the world of information (in good and bad) in their hands. We figure that the more we let the students study together in their own spaces, digital or in flesh, the better. In a sense, this was an attempt to turn the lecture from a 'depositing information mode' (Freirean banking method) to an 'oasis mode' in which the metaphor of oasis calls for such images as restfulness, peacefulness, and refreshment of learning-something that the Danish term hygge tries to capture (see Larsen 2019). This emphasis linked our course also with the tradition of critical pedagogy (see e.g. McLaren and Kincheloe 2007; Giroux 2011). In the context of critical pedagogy or 'digital sociology pedagogy' (Selwyn 2019), we meant to support 'individuals to learn how to make connections, develop the capacity to know more, nurture, and maintain connections to support continual learning, and be able to choose what is best to learn at any particular time' (Selwyn 2019: 99), which is something we think is also at the heart of the Millsian sociological imagination. In the words of Paulo Freire, a founding figure of critical pedagogy, our aim was to encourage the students to 'read the word and the world' (see Freire and Macedo 1987).

Perhaps we are 'postdigital' teachers-students-scholars, all at once, as we like to mix in our teaching practice digital-spaces and meatspaces, that is, learning activities both in digital platforms and in classrooms. At least our method as university level adult educators demanded that we define ourselves not as 'legislators' who always already know (of course there is no denying that we do know some things), but more as 'interpreters', who do not play ball only together but pass it to our students, too. And this is a crucial starting point. We cannot really know what our students will learn, or what are their personal and social meaning-making practices pertaining the ongoing course. We can set our own aims and express our wishes, but what else?

In terms of pedagogical technology, we had a multimodal approach: In addition to Wikiversity as our main digital platform, we resorted to the university's password protected Moodle learning environment only as a storage of the copyrighted readings. In addition, we organized discussion lectures in the meatspace of Tampere University's campus. The students had independent study groups for their weekly assignments and they set up the Wikiversity pages for the groups as we, too, did for the two of us (we wrote the first draft of this text on it as the course proceeded). Alongside, these practices the students were expected to form reading groups to read a sociological biography of $\mathrm{C}$. Wright Mills (Suoranta 2017). So, the students had to read, search the Internet, do group assignments, upload their small group minutes to their groups' Wikiversity pages, and 
participate in the discussion lectures. Thus, they were able to practice most of the social scientific craftsmanship Mills sorely emphasizes in The Sociological Imagination.

We gave special emphasis on Wikiversity, for we wanted the students to learn the value of studying and learning together, and how the results of that epistemic collaboration should be publicly available for all as in Wikiversity. In addition to its free and open source policy, part of the beauty of Wikiversity is that eventually all the courses will comprise an archipelago of free and public learning resources. (Suoranta 2010.)

Besides trying to create a sociologically imaginative course in terms of its pedagogical form, we wanted to explore the realms of the sociological imagination in the course contents. We think that there is no such thing as social sciences 101 , or any other sociology as already thought anymore. Thus, the contents we introduced were not ready-made packages, but more like invitations to think and reflect. Sociology and its objects are in constant flux and the sociological era is - to say the least-'postmethodological' and 'multiparadigmatic'. In these apparently messy conditions, we divided our course topic - social scientific imagination - into seven themes as follows: intellectual craftsmanship of social scientists; action and the problem of social order; power and social classifications; a sense of possibilities and the politics of imagination; enriching the imagination I: sounds, voices, and images; enriching the imagination II: fiction; and enriching the imagination III: sociology of feelings. Every week the students had their group discussions, based on readings, which they then uploaded into their own Wikiversity pages for all of us to read before the discussion lectures.

\section{Reflective Teaching Diary}

\section{Week One}

After the general introductory notes and information on how the course would proceed, we briefly took up the topic of our discipline by reminding the students that it is hard if totally impossible to grasp the current condition of the social sciences from the point of view of sub specie aeternitatis, that is, timelessly and atopically, but always sub specie temporis, that is, in relation to a certain time and place. But still it makes sense to assume that there are some qualities of thought that in our field could be captured under the notion of the sociological imagination. In trying to demonstrate what is meant by imagination, we asked half of the students to imagine a situation in which a student had received a positive feedback of their Master's thesis from their supervisor and the other half to imagine an opposite case. In this, we used the method of empathy-based stories in which the respondents are asked to write short essays by picturing themselves in a situation that is described to them in a sheet of paper as a 'frame story' (see Wallin et al. 2018; Särkelä and Suoranta forthcoming ).

A certain undercurrent of the course was the fight against 'a belief in which all social and economic problems can always and only be solved through a free market economy' (Denzin and Giardina 2015: 12). One unfortunate result of this state of affairs in the university sector and societies at large, especially when associated with the present-day right-wing Manichaeism and its assault on public reason, is that the abilities and spaces to practice different forms of imagination - social, sociological, political, transgressive - are in danger. Without skillful and hopeful use of imagination and critical reflection, life easily turns into an empty mechanical performance of random operations. 


\section{Week Two}

My impression is, based on students' notes in their Wikiversity group pages, that they found interesting the text 'On Intellectual Craftsmanship' by Mills that we included in the course readings. At the same time, I felt that we would do well if we discussed the methodological 'seasons' in social sciences to paint a broad picture of the cycle of the methodological shifts in social sciences. An established account of these seasons or changes throughout the decades has been given by Denzin and Lincoln (2018). Perhaps we could use that? Or maybe we could also talk about the politics of research methods - a direction taken by Denzin and others who argue that qualitative researchers are under conservative challenge and have become almost like an endangered species in the methodological discussions and debates in the social sciences over the past years (Denzin 2009).

As I pondered this question, I remembered Mills's note on the 'new practicality' and the administrative approach in the social sciences that prevailed in the 1950s. He writes that the

new practicality leads to new images of social science - and of social scientists. New institutions have arisen in which this illiberal practicality is installed: industrial relations centers, research bureaux of universities, new research branches of corporation, air force, and government. They are not concerned with the battered human beings living at the bottom of society - the bad boy, the loose woman, the migrant worker, the un-Americanized immigrant. On the contrary, they are connected, in fact and in fantasy, with the top levels of society, in particular, with enlightened circles of business executives and with generals having sizeable budgets. For the first time in the history of their disciplines, social scientists have come into professional relations with private and public powers above the level of the welfare agency and the county agent. Their positions change - from the academic to the bureaucratic; their publics change - from movements of reformers to circles of decisions-makers; and their problems change - from those of their own choice to those of their new clients. (Mills 1980: 108.)

Does not this sound a lot like social sciences and scientists of our times if we expand the private and public powers also to various supranational organizations such as the EU and OECD?

A note from today's meeting with the students (a.k.a lecture): The power of a group. Our students are well prepared and qualified to do their weekly group work, that is, they get the point of the assignments - and they far exceed our expectations. What is it then that does the trick as they start to relax and speak their mind in the meetings? The answer may be the power of the (study) group, their group discussion, and collaboration before the weekly meetings. For they indeed are meetings, not traditional lectures: we converse and change shifts almost as if in jazz. Collaborative teaching as jazz.

\section{Week Three}

Today's topic was the concept of action and how to understand social action. However, it happened to me in the weekend before the class and at the end of the last week as I 
was preparing our next lecture/meeting that I froze. I felt that I have nothing to say, that I do not know anything. Finally I will be exposed as a fake Professor! The students had their group assignments as in the week before, and they had done them. But the topic itself proved simply too large to talk about within the confines of one class. Damn! Was I a victim of an imposter syndrome - an anticipation of shame and a fear that others will finally see our weaknesses and shortcomings and how dumb we actually are, 'that around the corner is an unforeseen but cataclysmic event that will reveal us as frauds' (Brookfield 1995: 230)? The gnawing feeling will not go away. It cannot be wished away. But I have found out that teaching with a colleague, with you, eases the pain and the psychological burden amidst the terror of 'neoliberal syndrome' inside the present university. Collaborative teaching brings me comfort, safety, and very often joy.

Let me add something. Even though it was not my turn to be in charge and take the lead, I was prepared to speak a little of how action is always relational, that is, how no agent is the origin of the things achieved or even of one's own action, but any action is to some extent received, a response to an invitation, as it is conditioned and constituted by others. There is thus no 'pure' action, but any action is a mixture of activity and passivity. Action is always dislocated, distributed, influenced, and translated. But today's class took another course and I never got to say any of these things at any point. At first I felt disappointed of myself. I sensed that we - or rather I-had failed. We had not really succeeded in helping the students to understand what action is. But afterwards, to me this only illustrated what I was planning to say. Teaching, just like any action, is subject to unforeseen twists, interruptions, disruptions, and changes of direction. I also realized that when you put yourself out there, it is inevitable that sometimes you are just bound to fail. You cannot have absolute control over the outcome, and that goes for any action. So at least, to me this failure taught something about action and teaching. And I was reminded of the fact that while the students are our fellow teachers, to really learn with them we need to preserve or enliven what is young in us and become their fellow students. (Thus it is possible, as Burawoy (2005: 9) has stated, that 'education becomes a series of dialogues on the terrain of sociology that we foster - a dialogue between ourselves and students, between students and their own experiences, among students themselves, and finally a dialogue of students with publics beyond the university.') - And in the end, could it be that we had dropped the ball for the simple reason that action is one of the core concepts of the social sciences, and we faced the same destiny as Saint Augustine (2006: 242) in trying to capture the meaning of time: 'What then is time? If no one asks me, I know what it is. If I wish to explain it to him who asks, I do not know.'

\section{Week Four}

This week it happened: the class became truly interactive. There was a lively dialogue; the students not only asking questions from us, but also sharing their ideas directly with each other and commenting on each other's comments. This also changed our roles as teachers: we two stopped being those who talk at students and instead became more like hosts offering a space for discussion and overseeing it.

As much as I occasionally enjoy lecturing, I find the Slavic inexpressiveness of the audience - which is something that just happens every now and then, especially in our home country - very uncomfortable. You are hungry for signs, but you cannot read 
anything from the facial expressions of the members in the audience. You cannot tell whether they understand at all what you are saying, whether they are following you or not, or whether they are just bored. In those moments, in the absence of dialogue and feedback, the lecture theatre becomes a very lonely place. This always makes me think of Gèrard Petitjean's interview with Michel Foucault in Le Nouvel Observateur in 1975, where he speaks of that loneliness: 'Sometimes, when the lecture was not good, something, a question, was needed to bring it all together. But the question never comes ... And as there is no feedback, the lecture becomes a piece of theatre. My relationship with the people who are there is that of an actor or an acrobat. And when I have finished speaking, a feeling of total solitude.' (Macey 2019: 245.) But today, we were saved from the metaphysical loneliness of the academic actor or acrobat. And I would say that it was not so much thanks to us as to the students and the topic of discussion which seemed to resonate in them. We discussed the reception of a book on the economic elite in Finland, freshly published by our colleagues (Kantola and Kuusela 2019). There was nothing extraordinary in the first part of the class that would have suggested in the direction of a great discussion to come. In fact, we started off by a fairly traditional short lecture on classification and power. I even showed some PowerPoint slides, although I had understood that we had tacitly agreed on not using them during the course. But still there was this fantastic, lively dialogue, while 'death by PowerPoint' (Back 2016) (where technology may at worst only serve the aforementioned intellectual masturbation) could have equally taken place as well, maybe even more likely. Perhaps this just shows how you can never anticipate and have absolute control over whether a dialogue takes place or not. It catches you by surprise. Perhaps all you can do is become 'worthy of the event' (Deleuze and Guattari 1994: 160).

\section{Week Five}

The purpose of the social sciences is not only to show how things and people are, but also how they could be. This emphasis comes from young Marx (1845) who famously stated that philosophers have so far only interpreted the world, but the point is to change it. Changing the world is at the same time a natural and enormous task for a social scientist, and it too demands interpretive work. Thus, both objectives, those of accurately presenting the world and changing it, can be creative and imaginative effort, depending on how talented a sociologist is. In recent decades, especially if compared to the 1970s, the target of changing the world has been disappearing from the social science curricula (of course, we only speak from our locality). Therefore, in today's class, we wanted to discuss the methodology of activist research strategies and approaches such as participatory action research in connection to the tradition of conflict theories in sociology.

We did not so much bring up dry and worn out methods as give examples of actual research practices. The first was David Graeber's The Democracy Project (2013), an emic description and analysis of what happened in Occupy Wall Street (OWS) in New York City in 2011. It is a study on the possibility and socio-political conditions of direct democracy, social change, and radical imagination. As one of the pioneers of the movement himself, Graeber describes in close range how the movement was invented, what was needed in getting it going, and what were its larger societal impacts in a few 
year's perspective. The other example used was Juha Suoranta's Hidden in Plain Sight (2011), a participatory action research based on the author's experiences in helping an underaged asylum-seeker in danger to be deported to life-threatening circumstances. By these examples, we wanted to remind our students that in the social sciences it is possible and often even desirable to join forces with other people and take sides with the oppressed and other groups in the fringes of a society. We also wanted to underline that social scientists can be committed and struggle for equal rights and social justice and still remain objective in their research.

These two objectives - being committed yet objective - are not contradictory, for a social scientist can make objective, that is, theoretically rigorous and methodologically sound research, whilst standing beside and acting with the underdog. But the committed sociologists cannot and need not stand alone, for they have little impact if they do not join forces with larger social movements. And, as Connell (2000) has argued, this 'being-with' others in different social and grassroots movements will also transform social sciences into a more collective and democratic endeavour. In sum, we condensed the lessons of these two illustrative examples into a simple formula: action + reflection $=$ activist, democratic-driven social research. Another exciting additional topics which would have fitted nicely into the week's agenda (maybe next year!) would have been 'public digital sociology' (see Selwyn 2019; Schneider 2014) and variations of digital activism.

\section{Week Six}

For this week's class, which was on sound and images and how they could stimulate the sociological imagination, I had asked my partner to call me at 16:25, ten minutes after the start of the class, because I wanted to flesh out a point to the students. I figured that by the time she would be calling I would have got to the part where I would talk about the cultural valuation of sound. And the timing was perfect. When my mobile rang, I casually took the call. When I said to my partner on the phone that I'm giving a lecture at the moment but surely I can chat for a while, I noticed for my delight how some students were flabbergasted, or even morally upset, shaking their heads and snorting in annoyance and disbelief. After I had hung up, I started to explain to the students that the difference between noise and meaningful communication is relative and situational: The mobile phone ringing in the middle of a lecture amounts to noise, as it interrupts the lecture and disturbs. However, when I answered the call and started chatting with my partner, the lecture became noise to us on the phone. And I gave the point more substance by shortly discussing Michel Serres's (2007) notion of the parasite. The parasite is the one who or that which intervenes and interrupts. Serres suggests that the way parasitology understands biological parasites like tapeworms, fleas, vermin, flukes, and lice 'bears several traces of anthropomorphisms' (6), as it speaks of hosts and guests, thus using the vocabulary of hospitality and hostility. What is more, in information theory, the parasite designates noise, static, a break in the message. The neighbouring function of eating is making noise: the open mouth that eats also emits sound.

With regard to the mobile phone experiment, there was a serendipity in the very beginning this week's class. When I entered the lecture theatre you ran off from the lecture theatre with your mobile phone looking all busy and stressed. I was happy, yet 
trying to hide my sneaky smile from the students. It was as if we had cunningly planned the whole thing, having not only one but two interruptions caused by a mobile phone! But of course that was not the case, and I had not told even you about the phone call I was about to receive from my partner.

But there was yet another unexpected twist to the class. As I entered the lecture theatre, the lights were dimmed. You had set up a Youtube video ${ }^{2}$ to the two gigantic screens displaying a walk on the streets of New York in rain. As you suddenly ran off, I did not get a chance to ask you what it was all about. So I just had to improvise. I started to talk about the wealth of stimuli and the fleeting contacts of the modern metropolis. I mentioned Georg Simmel's essay 'Die Grosstädte und das Geistesleben' ([1903] 1995), known as the 'metropolis essay' in the Anglophone world. In the text, Simmel explores the psychological foundation of urban individuality. According to Simmel, in order to be adapt themselves to the wealth of stimuli and to the bombardment of the senses, the urbanites need to develop a particular way of reacting to external stimuli, a specific 'protective organ' (Simmel [1903] 1995: 117). The bustle of life in the metropolis demands heightened intellectualism from its inhabitants. Instead of reacting emotionally, so Simmel suggests, the urbanites need to react with their intellect, favouring a distanced, indifferent relationship to what they encounter in the urban cityscape. As a happy coincidence, the video made perfect sense, because I had prepared to say a few words on Guy Debord's Society of the Spectacle during the lecture. In a famous quote from the book, Debord (2014: 2) suggests that: 'In societies where modern conditions of production prevail, all life presents as an immense accumulation of spectacles. Everything that was directly lived has moved away into representation.' And here we had the streets of New York under our very eyes as an audio-visual representation. The serendipities of this week's class exemplified eloquently and vividly how we cannot entirely control the end result of the lecture. A lecture is not something that we do, but it is an Event, something that happens.

\section{Week Seven}

I need to make a confession. This week's class made me realize how difficult it actually is to undo the conventional authority structure of the lecture theatre, as the age-old role of the omniscient teacher we have adopted and accustomed to sits so firmly in us that it cannot be shaken off just like that, by a simple wave of the hand. As university teachers, we must always face the question: What am I doing here? Am I teaching the students the facts, provide them with information, or something else? The question is pondered by Hoskins (2019), a retiring biology professor: 'Could I have conveyed more information per minute by talking at my students? Sure. But that's not how I wanted to teach. My students already knew how to learn facts. I wanted them to think deeply about the research process and to develop their own inventiveness. I wanted them to tap into their imaginations.' This is an answer we want to cling to! And add to the choir the words of our favourite philosopher of science, Feyerabend (1993: 11), who states that the history of science is 'as complex, chaotic, full of mistakes, and entertaining as the ideas it contains, and these ideas in turn will be as complex, chaotic,

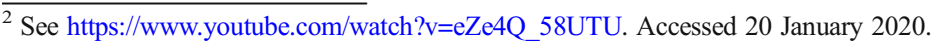


full of mistakes, and entertaining as are the minds of those who invented them'. Mutatis mutandis, perhaps, and quite possibly, the same goes with teaching social sciences.

The topic of the class was the use of fiction in research and how fiction could potentially enrich the social scientific imagination. We had asked the students to read a small selection of short stories by the Finnish author Rosa Liksom ${ }^{3}$ for this week's class, and their group assignments were brilliant, bursting with great insights that we were keen to discuss with the students. However, as I had just co-edited a special issue on the topic, I got carried away. I started lecturing and went on and on and on. And because of this rumbling monologue of mine, we ended up having very little time for collective discussion. Fortunately, the thoughts of the groups were nevertheless to be found on the course platform and could be accessed by anyone interested in seeing what their fellow students had thought about the short stories by Liksom.

\section{Week Eight}

In today's class, we discussed emotions. Emotions and affective experiences usually have no place in traditional academic discourse on conducting research, which is considered to be characterized strictly by the use of reason. It is as if true scholars worthy of the name were beings of reason completely devoid of affects, emotions, and desires, and related to their object of study indifferently, with their intellect only. Yet we do feel. And we may have negative emotions. According to the sociologist and feminist cultural theorist, Rosalind Gill, in the neoliberal university, many academics are ridden with feelings of uncertainty, increased stress, exhaustion, anxiety, insomnia, fear of exposure, and shame that 'remain largely secret and silenced in the public spaces of the academy' (Gill 2009). Gill insists that we need to break the collective silence surrounding these feelings. It is important not only to bring them out in the open, but also see how they are connected with neoliberal practices of power in contemporary academia. For speaking about overload and about such negative feelings as exhaustion, anxiety, and shame should not be taken merely as moaning or complaining, but as an instance of resistance and as an important demand for change (Gill 2009).

Acknowledging that quite possibly students, too, are in need of a valve to let their feelings out, we set up a separate compartment on the course's Wikiversity page where the students could anonymously express their emotions at will. Some of the texts were poemlike, while others resembled more entries from a personal diary. It was highly expected that only few of the students would reflect their emotions in the 'emotion diary' as we called the page, and that was alright. We did not want to force them to express their feelings, but only provide them with a forum. And the thoughts they wrote were touching. What was salient was that they wrote a lot about problems and negative feelings such as anxiety, but were mostly silent about joy and other positive feelings. Our guess is that the same would more or less apply to teachers and researchers as well, had we asked them to write about their emotions and affective experiences at this particular juncture of university work defined by positivist rationality and technocratic managerialism that reign the university sector in basically every corner of the world.

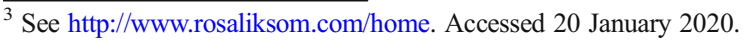




\section{Conclusion: Week Nine}

Today we had our final meeting, so it was time to sum up what we all had learned in the class and discuss the new insights gained. For me, one of the most delightful things that happened in today's class was when some of the students mentioned how the course had helped them to loosen up a bit and to some extent let go of the coercive highperformance mentality that they had largely internalized during their previous studies. Hearing that made me feel that we had really accomplished something. If there's at least the slightest chance that we have succeeded in creating a space of togetherness where we would not care so much for grades and points, but instead just do things together out of sheer joy and interest, for the fun of it, then I feel that we have achieved something wonderful. I think the most important career advice and life lesson one could give a younger colleague is to do things out of interest, joy, and passion rather than constantly think strategically about where what you do will take you. Thinking strategically will instrumentalize the work and kill all the fun and creativity.

In today's class, we also tried to make clear what was the point of it all. Or, to be honest, we had not prepared to do this, but we had no choice, as a student raised her hand and posed a question about it. First we panicked, but then we explained that rather than on content the focus was on form, so to speak: we did not so much aspire the students to learn certain pieces of information or a body of knowledge as to learn how to think. While the use of imagination cannot perhaps be taught or trained, we firmly believe that it can nevertheless be cultivated. And our idea was to stimulate and feed the students' social scientific imagination by making connections and offering them impulses which would possibly give rise to new ideas, alternative perspectives, and different ways to think. We encouraged them to ask questions and keep on questioning existing reality. For stepping out of what exists to think what does not exist and how things could be otherwise is what imagination is all about (see also Swedberg 2014). That also goes for the university. Instead of merely complying with rules and being docile vassals, or empty vessels for us teachers to fill, students are actually capable of changing the university and building it to what they want and imagine it to be. Our experience tells us that the basic ingredients of good learning in higher education are as follows: self-direction, collaboration, responsibility, and enthusiasm.

During the course, we met with the students for nine weeks in the formal conditions of a university lecture hall. Standing and occasionally sitting in front of them, we spoke most of the time. In this respect, the course resembled the tradition of a mass university and an authoritarian educational model if not the Freirean banking model. Yet the students also had their assignments and their semi-formal meetings in the plurality of spaces with access to information sources with mobile technologies. These postdigital practices 'are blurring the borders of what it means to study at a university' (Lindén et al. 2019: 84). Despite the use of various learning spaces, digital learning platforms, digital reading materials, and group work we take the words of Karpiak (2010: 13) into our hearts as she states that,

as educators we come to know our students through their participation in class, their productivity on tests and exams, and through various personal encounters. Seldom do we know them through their stories. Rarely are we privileged to read their less formal and more personal works, or witness their unique personalities 
and literary styles. Scarcely ever do we engage with their life struggles, their efforts to survive, or their capacities to adapt, to learn, and to change. And even less do we glimpse into their life as learners and the ways in which learning, change, and education at times coexist and at other times collide in the course of their development. And to be sure, our knowledge of them, as we know them, may be quite sufficient for the purposes of traditional academic courses; but in having only this more impersonal knowledge of them, could we be perhaps missing something of a deeper nature - the "inside" view? Could we be missing also the opportunity to attend to their desire not only to know, but also to "become" known to themselves and to others?

We did not get to know our students in person, participate in depth in their development as lifelong learners, or have an inside view to their learning processes; that was impossible in the era of the massification of higher education, and for that matter, not even desirable. Just like good behaviourists we had to settle for the students' learning outcomes in their study circle reports and their minutes in the Wikiversity pages.

Earlier, based on our experience from our course in the Autumn semester in 2018, and referring to practice theory (Reckwitz 2002) and to the idea of education as critical praxis (Freire 1993), we suggested that the 'postdigital' could be defined 'as a form of "community of praxis" in which praxis refers to reflection (group and classroom discussions) and action (organizing groups work and writing wiki comments)' (Arndt et al. 2019: 460). After this year's (2019) teaching experience, we are inclined to suggest that what gradually happened in our 'postdigital classroom' and outside of it during the nine weeks together with our students - and this realization came only after the fact, as we reflected the course via writing this text-was an Event. What is more, in this case the Event was of a postdigital kind, as various digital technologies, combined with face-to-face interaction, were constitutive of it.

What we mean by an Event is, firstly, that during the weeks that we- - the students and us - spent together (and most of that time we spent separately) around the themes of the social scientific imagination, there developed and evolved a social and communicative practice of knowledge production, and the weekly classes formed a connecting knot and a call for a journey in learning. This was proved by some of the students' evaluations as they stated that during the ongoing semester, their attitudes had changed and they had put learning ahead of simply performing well.

Secondly, we suggest that the course - and any course, in fact - amounts to an Event also in that the outcome and its occurrence are partly beyond control. In the postdigital context, this is already due to the fact that technology is irreducible to a perfectly loyal, passive instrument of action. It always modifies, mutates, and transforms what it mediates; the space in-between is a 'space of transformation' (Serres 2007: 70). So, while the class was carefully managed in spatiotemporal terms (by being given an even rhythm of weekly meetings, which took place on a specific day and exact hour for a given time in a well-defined place), and while each meeting had a set structure and programme planned well in advance, what came out of it all was nevertheless to some extent surprising and unexpected. Philosopher Jean-Luc Nancy has claimed that surprise is not an element of the Event but the Event itself, the peculiar way of being of Events. For Nancy, 'the surprise of the event is a 'tautology': the event either surprises or is not an event' (Nancy 2000: 167). Thus, the Event is irreducible to its 
conditions of possibility. As Derrida (2005: 18) expresses it, 'It is not enough that something may happen for it to happen; hence an analysis of what makes an event possible [...] will never tell us anything about the event itself'. The possibility of a pedagogically successful learning experience can never fully guarantee for such an experience to take place. There is no recipe for an Event. No Event can be accounted for by listing the elements that go into it. It happens - if it happens to happen - inbetween, in the encounters between the elements coming together.

Thirdly, the Event does not leave the elements untouched and unchanged, but all those involved leave the Event transformed. 'They all leave their meeting in a different state from the one in which they entered', as Latour (1999: 127) suggests. Neither we teachers nor the students remained the same. The changes may have been so small that they are hardly even visible, but we sincerely hope that the students acquired new ideas and competences thanks to the course, just as we most certainly did, or at least a sparkle of hope and imagination.

\section{HAMM (anguished):}

What's happening, what's happening?

CLOV:

Something is taking its course.

Samuel Beckett, Endgame (1957)

Open Access This article is licensed under a Creative Commons Attribution 4.0 International License, which permits use, sharing, adaptation, distribution and reproduction in any medium or format, as long as you give appropriate credit to the original author(s) and the source, provide a link to the Creative Commons licence, and indicate if changes were made. The images or other third party material in this article are included in the article's Creative Commons licence, unless indicated otherwise in a credit line to the material. If material is not included in the article's Creative Commons licence and your intended use is not permitted by statutory regulation or exceeds the permitted use, you will need to obtain permission directly from the copyright holder. To view a copy of this licence, visit http://creativecommons.org/licenses/by/4.0/.

\section{References}

Arndt, S., Asher, G., Knox, J., Ford, D. R., Hayes, S., Lăzăroiu, G., Jackson, L., Mañero Contreras, J., Buchanan, R., D’Olimpio, L., Smith, M., Suoranta, J., Pyyhtinen, O., Ryberg, T., Davidsen, J., Steketee, A., Mihăilă, R., Stewart, G., Dawson, M., Sinclair, C., \& Peters, M. A. (2019). Between the blabbering noise of individuals or the silent dialogue of many: a collective response to 'Postdigital science and education' (Jandrić et al. 2018). Postdigital Science and Education, 1(1), 446-474. https://doi. org/10.1007/s42438-019-00037-y .

Augustine. (2006). In M. P. Foley (Ed.), The Confessions. Indianapolis: Hackett Publishing Company.

Back, L. (2016). Academic diary: or why higher education still matters. London: Goldsmiths Press.

Beckett, S. (1957). Endgame. London: Farber \& Farber.

Berger, J., \& Quinney, R. (2005). Storytelling sociology: narrative as social inquiry. Boulder: Lynne Rienner. Brookfield, S. (1995). Becoming a critically reflective teacher. San Francisco: Jossey-Bass.

Burawoy, M. (2005). For public sociology. American Sociological Review, 70(1), 4-28. https://doi. org/10.1177/000312240507000102.

Connell, R. W. (2000). Sociology and the world market. Contemporary Sociology, 29(2), 291-296.

Debord, G. (2014). The society of the spectacle. Trans. K. Knabb. Berkeley: Buraeau of Public Secrets. 
Deleuze, G., \& Guattari, F. (1994). What is Philosophy? Trans. H. Tomlinson \& G. Burchell. New York: Columbia University Press.

Deleuze, G., \& Parnet, C. (2006). Dialogues II. Trans. H. Tomlinson, B. Habberjam, \& E. R. Albert. London and New York: Continuum.

Denzin, N. (2009). Qualitative inquiry under fire. Toward a new paradigm dialogue. Walnut Greek: Left Coast Press.

Denzin, N., \& Giardina, M. (2015). Introduction: Qualitative Inquiry and the Politics of Research. In Denzin, N., \& Giardina, M. (Eds.). Qualitative Inquiry and the Politics of Research. Walnut Greek: Left Cost Press.

Denzin, N., \& Lincoln, Y. (2018). The SAGE handbook of qualitative research (5th ed.). Thousand Oaks: SAGE.

Derrida, J. (2005). The politics of friendship. Trans. G. Collins. London, Verso.

Feenberg, A. (2019). Postdigital or Predigital? Postdigital Science and Education, 1(1), 8-9. https://doi. org/10.1007/s42438-018-0027-2.

Feyerabend, P. (1993). Against method. London: Verso.

Freire, P. (1993). Pedagogy of the oppressed. New York: Continuum.

Freire, P., \& Macedo, D. (1987). Literacy. Reading the word and the world. Westport: Bergin \& Garvey.

Gill, R. (2009). Breaking the silence: the hidden injuries of neo-liberal academia. In R. Flood \& R. Gill (Eds.), Secrecy and silence in the research process: feminist reflections. London: Routledge.

Giroux, H. (2011). On critical pedagogy. New York: Continuum.

Graeber, D. (2013). The democracy project. A history, a crisis, a movement. New York: Spiegel \& Grau.

Harland, T. (2016). Teaching to enhance research. Higher Education Research \& Development, 35(3), 461472. https://doi.org/10.1080/07294360.2015.1107876 .

Hayes, D. (2019). How the university lost its way: sixteen threats to academic freedom. Postdigital Science and Education. https://doi.org/10.1007/s42438-019-00079-2 .

Hoskins, S. (2019). How I learned to teach like a scientist. Science, 13 June. https://www.sciencemag. org/careers/2019/06/how-i-learned-teach-scientist . Accessed 13 November 2019.

Jandrić, P. (2017). Learning in the age of digital reason. Rotterdam: Sense Publishers.

Jandrić, P., Knox, J., Besley, T., Ryberg, T., Suoranta, J., \& Hayes, S. (2018). Postdigital science and education. Educational Philosophy and Theory, 50(10), 893-899. https://doi.org/10.1080 /00131857.2018.1454000 .

Kantola, A., \& Kuusela, H. (2019). Huipputuloiset. Suomen rikkain promille ('The super rich. Finland's richest minority'). Tampere: Vastapaino.

Karpiak, I. E. (2010). Summoning the past: autobiography as a 'movement toward possibility'. New Directions for Adult and Continuing Education, 126, 13-24. https://doi.org/10.1002/ace.368.

Knox, J. (2019). What does the 'Postdigital' mean for education? Three critical perspectives on the digital, with implications for educational research and practice. Postdigital Science and Education, 1(2), 357370. https://doi.org/10.1007/s42438-019-00045-y .

Larsen, M. (2019). Hygge, Hope and higher education: a case study of Denmark. In P. Gibbs \& A. Peterson (Eds.), Higher Education and Hope (pp. 71-89). Cham: Palgrave Macmillan.

Latour, B. (1999). Pandora's Hope. Essays on the reality of science studies. Cambridge, MA: Harvard University Press.

Lindén, J., Kanninen, M., Kupiainen, R., \& Annala, J. (2019). Sensing the same space - spatial understanding and engagement in higher education. Dansk Universitetspaedagogisk Tidskrift, 15(27), 83-97.

Macey, D. (2019). The lives of Michel Foucault. London: Verso.

Marx, K. (1845). Theses on Feuerbach. https://www.marxists.org/archive/marx/works/1845/theses/. Accessed 8 January 2020

McLaren, P., \& Kincheloe, J. (2007). Critical pedagogy. Where are we now? New York: Peter Lang.

Mills, C. W. (1980). The sociological imagination. New York: Penguin Books.

Nancy, J.-L. (2000). Being singular plural. Trans. R. D. Richardson and A. E. O'Byrne. Standford: Standford University Press.

Neary, M., \& Winn, J. (2015). Beyond public and private. A model for co-operative higher education. Krisis, 2. https://krisis.eu/beyond-public-and-private/ . Accessed 27 October 2019.

Norris, J., Sawyer, R. D., \& Lund, D. (2012). Duoethnography: dialogic methods for social, health, and educational research. Walnut Creek: Left Coast Press.

Pyyhtinen, O. (2015). More-than-human sociology: a new sociological imagination. Basingstoke: Palgrave Macmillan. 
Pyyhtinen, O. (2019). Introduction to the special section 'Fictioning social theory: the use of fiction to enrich, inform, and challenge the the theoretical imagination'. Digithum, 24, 1-9. https://doi.org/10.7238/d.v0 i24.3188.

Reckwitz, A. (2002). Toward a theory of social practices. A development in culturalist theorizing. European Journal of Social Theory, 5(2), 243-263. https://doi.org/10.1177/13684310222225432.

Särkelä, E., \& Suoranta, J. (forthcoming 2020). The method of empathy-based stories as a tool for research and teaching. The Qualitative Report, 25(2).

Schneider, C. (2014). Social media and e-public sociology. In A. Hanemaayer \& C. Schneider (Eds.), The public sociology debate. Vancouver: UBC Press.

Selwyn, N. (2019). What is digital sociology? Cambridge: Polity Press.

Serres, M. (1997). The troubadour of knowledge. Trans. S.F. Glaser and W. Paulson. Michigan: University of Michigan Press.

Serres, M. (2007). The parasite. Trans. L.R. Schehr. Minneapolis: University of Minnesota Press.

Simmel, G. (1995). Aufsatäze und Abhandlungen 1901-1908 Band I. Georg Simmel Gesamtausgabe Band 7. Frankfurt am Main: Suhrkamp.

Suoranta, J. (2008). Teaching sociology: toward collaborative social relations in educational situations. Critical Sociology, 34(5), 709-723. https://doi.org/10.1177/0896920508093364.

Suoranta, J. (2010). Learners and oppressed peoples of the world, Wikify! In C. Malott \& B. Porfilio (Eds.), Critical pedagogy in the 21st century: a new generation of scholars. Charlotte: Information Age Publishing.

Suoranta, J. (2011). Hidden in plain sight. Helsinki: Into Publishing https://www.researchgate. net/publication/272506252_Hidden_in_Plain_Sight. Accessed 7 December 2019.

Suoranta, J. (2017). C. Wright Millsin sosiologinen elämä ['C. Wright Mills's sociological life']. Tampere: Vastapaino.

Swedberg, R. (2014). The art of social theory. Princeton: Princeton University Press.

Wallin, A., Koro-Ljungberg, M., \& Eskola, J. (2018). The method of empathy-based stories. International Journal of Research and Method in Education, 42(5), 525-535. https://doi.org/10.1080/1743727 X.2018.1533937.

Zuidhof, P.W. (2015). Towards a post-neoliberal university. Protest and complicity. Krisis, 2. https://krisis. eu/towards-a-post-neoliberal-university/ . Accessed 4 October 2019. 